\title{
Effectiveness of antidepressants for treatment of idiopathic orofacial pain
}

\author{
M Ikawa', M Ikawa ${ }^{2 *}$ \\ From The European Headache and Migraine Trust International Congress \\ London, UK. 20-23 September 2012
}

\begin{abstract}
Aims
To determine the efficacy of antidepressants for treating idiopathic orofacial pain fulfilling the International Classification of Headache Disorders 2nd edition (ICHD-II) criteria of persistent idiopathic facial pain (13.18.4; IFP) or burning mouth syndrome (13.18.5; BMS).
\end{abstract}

\section{Materials and methods}

Participants comprised 195 outpatients who attended our orofacial pain liaison clinic between January 1, 2009 and December 31, 2011 and were diagnosed with IFP or BMS. IFP was diagnosed in 124 patients (17 men, 107 women; atypical facial pain, $n=16$; atypical odontalgia, $n=108$ ), with a mean age of $54.8 \pm 14.4$ years and a mean duration of illness of $50.7 \pm 62.8$ months. BMS was diagnosed in 71 patients ( 8 men, 63 women; so-called BMS, $n=28$; glossodynia (pain limited to tongue), $\mathrm{n}=43$ ), with a mean age of $67.2 \pm 10.8$ years and a mean duration of illness of 23.1 \pm 27.3 months. Patients with mental disorders, including major depressive disorders, who were currently taking antipsychotic agents were excluded. All participants were treated with antidepressants, with first-line therapy comprising amitriptyline or another tricyclic antidepressant (TCA). If a TCA alone proved insufficient for pain control, one of the following agents was added to the TCA for combination therapy, in this order: risperidone; sodium valproate; or lithium. These other antidepressants were also used if the patient could not use TCAs due to underlying disease. Outcomes were assessed as: -effective, pain disappeared or no pain was experienced for $90 \%$ of each week; -moderately effective, pain improved, but did not disappear; -no effect, no change; and dropped out, including referral due to difficulty making visits because of the distance.

${ }^{2}$ Shimizu Municipal Hospital, Dept. of Oral Surgery, Japan

Full list of author information is available at the end of the article

\section{Results}

For IFP, treatment was effective for 91 patients (73.4\%), moderately effective, $3.2 \%$, no effect, $0 \%$, dropped out, $23.4 \%$. For BMS, treatment was effective for 56 patients (78.9\%), moderately effective, $4.2 \%$, no effect, $1.4 \%$, dropped out, $15.5 \%$.

\section{Discussion}

Use of antidepressants can be helpful in the treatment of idiopathic orofacial pain such as IFP or BMS.

\section{Author details}

${ }^{1}$ Shimizu Municipal Hospital, Japan. ${ }^{2}$ Shimizu Municipal Hospital, Dept. of Oral Surgery, Japan.

Published: 21 February 2013

Reference

1. Headache Classification Subcommittee of the. International Headache Society: The International Classification of. Headache Disorders G. Cephalalgia , 2 2004, 24(Supp 1).

doi:10.1186/1129-2377-14-S1-P47

Cite this article as: Ikawa and Ikawa: Effectiveness of antidepressants for treatment of idiopathic orofacial pain. The Journal of Headache and Pain 2013 14(Suppl 1):P47.

Submit your manuscript to a SpringerOpen ${ }^{\odot}$ journal and benefit from:

- Convenient online submission

- Rigorous peer review

- Immediate publication on acceptance

- Open access: articles freely available online

- High visibility within the field

- Retaining the copyright to your article

Submit your next manuscript at $\gg$ springeropen.com

\section{SpringerOpen ${ }^{\circ}$}

๑ 2013 Ikawa and Ikawa; licensee Springer. This is an Open Access article distributed under the terms of the Creative Commons Attribution License (http://creativecommons.org/licenses/by/2.0), which permits unrestricted use, distribution, and reproduction in any medium, provided the original work is properly cited. 